\title{
Labor and its Productivity in Andean Dairy Farming Systems: A Comparative Approach
}

\author{
C. Aubron, H. Cochet, G. Brunschwig and C-H. Moulin
}

\begin{abstract}
Globalization induces changes in the combinations of productions and activities within farming systems in all parts of the world. These changes can only be apprehended through an in-depth understanding of the mechanisms and diversity of these farming systems. Labor, as a major technical determinant of differences in competitiveness, is central in these transformations. The technical and economic analysis of labor in Andean dairy production in this paper illustrates this issue. Combining various scales of analysis of labor and productivity highlights the technical obstacles faced by Andean dairy farmers, demonstrates the technical and economic principles of these production systems, and puts them in a competitive context. This analysis also discusses the benefits of a labor-centered approach of farming systems.
\end{abstract}

Key words: labor, production system, livestock farming system, productivity of labor, dairy farming, Andes, Peru.

\section{Claire Aubron}

Montpellier SupAgro UMR Elevage des Ruminants en Régions Chaudes, 2 place Pierre Viala, 34060 Montpellier cedex 01, France; e-mail: aubron@ supagro.inra.fr

Hubert Cochet

AgroParisTech UFR Agriculture Comparée et Développement Agricole 16, rue Claude Bernard 75231 Paris cedex 05, France; email: hubert.cochet @agroparistech.fr

Gilles Brunschwig

ENITA Clermont-Ferrand, UR Elevage et Production des Ruminants

BP 3563370 Lempdes, France; e-mail: brunsch@enitac.fr

Charles-Henri Moulin

Montpellier SupAgro UMR Elevage des Ruminants en Régions Chaudes

2 place Pierre Viala, 34060 Montpellier cedex 01, France; e-mail: moulinch@ supagro.inra.fr 


\section{Introduction}

Since 1990, Peruvian dairy production has grown significantly in the Andes and on the Pacific coast, and to a lesser extent in the Amazonian foothills. Destined principally for the domestic market, dairy production represents a critical food issue for the nation as it provides products to a growing urban population that has one of the lowest levels of dairy consumption on the continent ${ }^{1}$. The growth in Peruvian dairy production along the coast and in the two main Andean dairy areas (Cajamarca, Arequipa) is attributable in part to the development of large dairy farms, some of which produce several thousand liters of milk daily (Bernet et al., 2001). In the Andes, however, the phenomenon is also due to the activity of thousands of small family production units, some of which operate under very precarious conditions in terms of access to means of production, distance to markets, geography, etc. On these farms, the sale of milk to industrial dairy plants and/or of homemade cheese ensures a relatively stable income and therefore plays a critical role in household food security. The existence of such farms alongside considerably more productive ones raises the questions of why dairy production has developed in such marginal zones and what its future prospects are.

The historical conditions of Andean dairy production in its current context of trade liberalization are analyzed elsewhere (Aubron \& Cochet, In Press). The approach in this article complements this research, focusing on production systems and describing their diversity and their technical and economic operations through an analysis of labor. Labor is crucial at both technical and economic levels: from a technical point of view, given the function of labor in biotechnical processes, it appears to be a determining factor in production systems; from an economic point of view, given the relationship between added value and the workload needed to create it, labor underlies measurable differentials in productivity. This article thus both explores how Andean dairy production systems function and discusses the methodological contribution of such an approach to furthering an understanding of the choices made by producers and their prospects for the future.

\section{METHODOLOGY}

\section{Study region}

We carried out in-depth field work in a peasant community of the Peruvian Andes complemented by several rapid surveys and a review of literature concerning eight regions of Ecuador, Peru, and Bolivia.

The Sinto community lies in a marginal region of the Andes which has seen increases in farmer dairy production over the past 15 years. It is located at an altitude ranging between 3,000 and 5,000 meters above sea-level in the Huancavelica region in Peru. The community occupies the highest part of a valley that runs down to the Pacific coast in Pisco (see fig. 1). The western side of the Andes is characterized by steep slopes and a very dry climate (Dollfus, 1982), both of which are major obstacles to dairy production. Sustained, year-round dairy production in Sinto is only possible thanks to the construction - begun at the end of the nineteenth century - of irrigation systems to collect and distribute water to fodder cropping areas during the eight-month dry season. Irrigated parcels are usually small (between $100 \mathrm{~m}^{2}$ and $1 \mathrm{ha}$ ) and sown with alfalfa. This pulse fodder crop, grazed following a rotation pattern,

\footnotetext{
${ }^{1}$ In 2002, the average dairy product consumption levels of Bolivia, Peru and Ecuador were respectively 35, 50 and 100 in milk equivalent units per habitant per year, butter not included.
} 
provides the basic feed for cattle and is complemented by rangeland grazing. The 350 families in Sinto observe a set of community-defined rules regarding the management of resources used in dairy farming (Aubron, 2005). While rangelands and irrigation water are managed collectively, each family cultivates its own plots which can be passed on by inheritance but cannot be sold. Cattle are privately owned, and families may possess from one to forty head.

Figure 1. Location of the dairy production systems studied

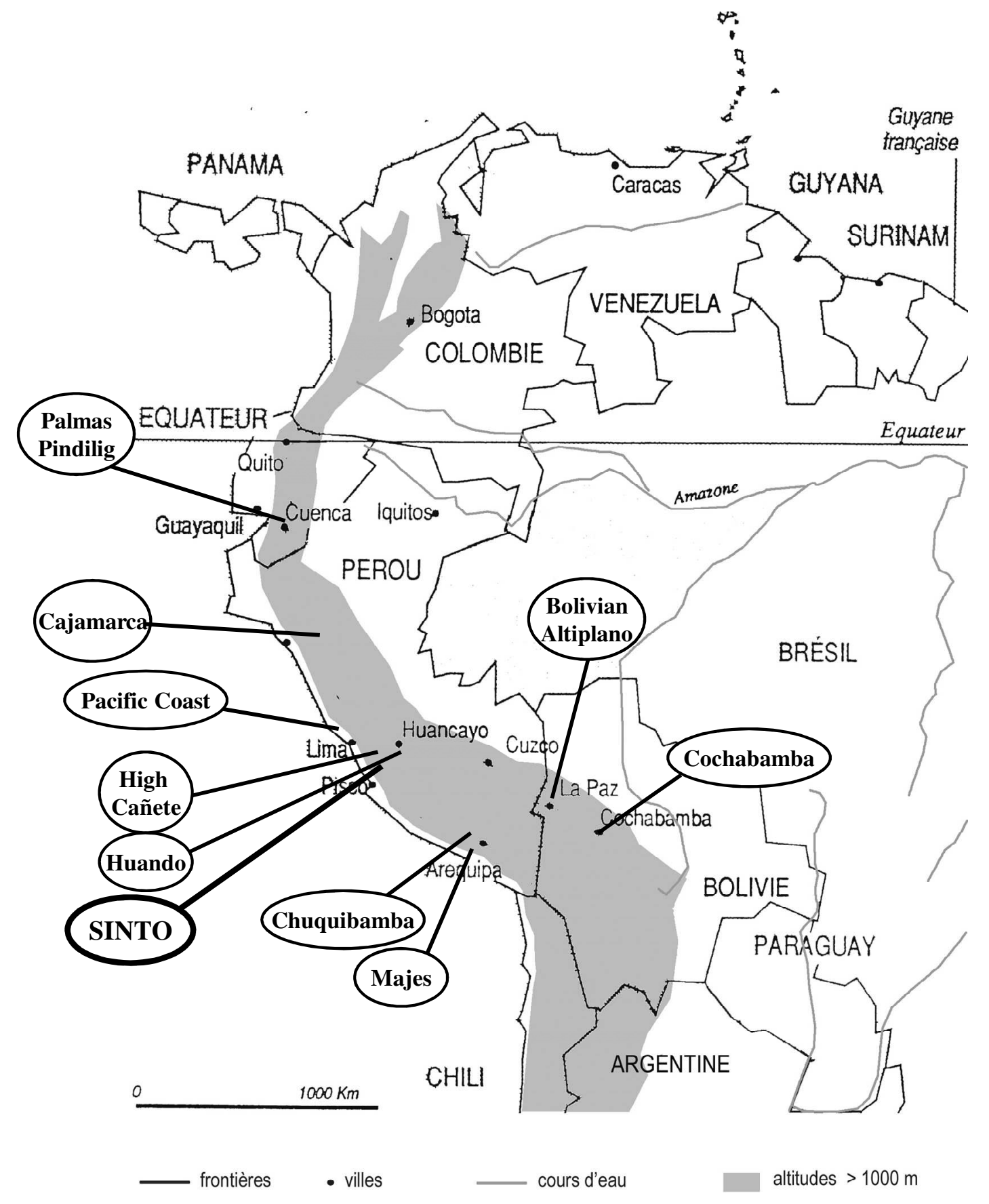


Sinto families are less diversified in terms of production than they were in the past as today they generally specialize in dairy farming. Some cereal and tuber crops for home consumption are usually cultivated, but the total area devoted to these crops does not exceed 10 to 50 acres per year and per family.

\section{Levels of analysis}

The first level of analysis is the basic production unit - most often the family-owned farm in the Andes. These farms constitute the core of rural life, establishing and shaping ties among neighbors, and constituting the context for decision-making ${ }^{2}$. At this level of analysis, the term, 'production system', designates a set of production units with access to comparable resources (similar geographic location, acreage, equipment, workforce) operating under similar socioeconomic conditions and practicing a given combination of productions (Cochet $\&$ Devienne, 2006). This allows us to measure the economic efficency of production process in relation to the labor force deployed or the land surface area used.

Further levels of analysis stem from the consideration of each basic production system constituted by farms as a specific combination of different cropping and livestock systems. The cropping system (Sebillotte, 1978) is an agronomic concept applied at the level of the plot or group of plots treated in a homogeneous manner, e.g., characterized by a succession of crops and possible associations of crops and by the set of techniques applied to them. The agronomic logic of a cropping system, which is linked closely to pedoclimatic and socioeconomic (access to land) conditions and physical constraints (accessibility and size of plots, etc.), is analyzed in terms of the system at plot level. An understanding of the decisions and practices of farmers should also be sought where cropping and livestock systems function together at the level of the overall production system (Cochet \& Devienne, 2006).

Similarly, livestock farming systems are defined at the level of a herd or part of a herd. They refer to "a set of dynamically interacting elements organized by man to valorize resources through the intermediary of domestic animals in order to obtain various products (milk, meat, skin and leather, manure, ...) or to respond to other objectives" (Landais, 1987). The livestock farming system itself is characterized by certain management and farming practices, strongly linked in space and time, which must also be analyzed in terms of system, feed often being the keystone (Cochet \& Devienne, 2006).

\section{Labor and its productivity in farming systems}

There have been numerous studies focusing on labor in cropping systems. Some examine the implementation and sequencing of cultivation operations (Morlon et al., 1996), while others focus on the organization of labor on special occasions such as harvests (Attonaty et al., 1987; Le Gal, 1997). Some researchers have also attempted to evaluate the economic productivity of labor in cropping systems, often in either a comparative perspective or to measure technical change (Hunt, 2000; Cochet, 2001; Nielsen et al., 2006; Ruben et al., 2006).

\footnotetext{
2 The important role played by the larger community in the organization of agricultural production in the Andes, is emphasized by numerous authors (Mayer, 1985; Gonzales de Olarte, 1984; Orlove et al., 1986; Mayer, 2002). The importance of the "collective" in the management of the dairy systems examined in this article (notably the management of rangelands and irrigation water teams) was studied in depth by one of the authors (Aubron, 2005).
} 
Nevertheless, the use of a labor-centered approach to analyze livestock farming is relatively new. Despite the difficulty of evaluating labor time requirements on a livestock farm given that most tasks are performed daily, some formal representations of labor planning have managed to take into account the specificity of daily chores (Dedieu et al., 2000; Madelrieux et al., 2006). Certain models of production units include a representation of daily and yearly work associated with livestock farming activities (Hervé et al., 2002). Other research projects have concentrated on herding tasks in pastoral systems (Stieff, 1997; Turner, 1999; Ayantunde et al., 2002). Linking this technical characterization with economic performance is difficult because most farm chores (with the possible exception of milking) are not strictly proportional to the size of the herd. Livestock farming can benefit from economies of scale the same size labor force is required to look after five or thirty cows on grazing lands whereas in cropping systems, the required work is strictly related to the size of the cultivated plot. Through this study of dairy production in the Andes, we aim to establish a link between analyses focused on the organisation of labor and those focused on economic performance.

Two economic indicators can be used to evaluate the economic efficiency of production systems, from the perspectives of both the creation of wealth and income, in order to compare performance in different groups of farms or in different regions: added value, which measures the wealth created by the production system, and agricultural income, which reflects the way added value is shared and which measures farmers' earnings. This research is focused on the first measurement - added value (including the values consumed by the farmer and his family) - and more specifically on the relationship between added value and labor force requirements known as the productivity of labor ${ }^{3}$.

The productivity of labor is a measure of labor efficiency and is a crucial concept in economics. However, it may be calculated differently depending on how the labor force is measured, i.e., either by hours or days of work or by number of workers. Due to the seasonality of most work in the agricultural sector, these two methods are distinct and produce different and complementary results. The added value calculated per worker - individuals available on the farm but not necessarily employed full time - measures the economic efficiency linked to one worker in a given production system, and therefore expresses the global productivity of labor. Yet the added value expressed per working day (or working hour) actually spent on various activities - also called daily productivity (or hourly productivity) of labor - may be useful in measuring the efficiency of labor at the level of cropping or livestock farming systems (Cochet, 2005).

Finally, to move from the measurement of labor efficiency (productivity) to its payment (farmers' earnings), one must deduct from the value added the portions of the latter allocated to (i) payment of land rent (if the producer does not own his own land), (ii) wages (if labor is hired), (iii) interest on borrowed capital where applicable, and (iv) payment of taxes. In the case of the Andean dairy systems here, producers generally owned their own means of production and only rarely required the help of wage labor. The level of labor productivity consequently gives a measurement that is very close to that of the remuneration of labor.

\footnotetext{
3 The "productivity of land," or the value added per surface unit, will not be addressed in this article. The measurement of the areas involved, since vast expanses of high altitude rangelands must be included, is particularly difficult. Here, only the gross value added (GVA), and thus the gross productivity of labor, was measured in so the fixed capital annual depreciation of the production units (remaining insignificant for the majority) could not be taken into account.
} 
In order to better understand Andean farming families' decision making in terms of assigning tasks among the family labor force, we assess the opportunity costs of family labor by measuring the productivity and remuneration of labor dedicated to different activities.

\section{Surveys, monitoring, and study of labor on Andean dairy farms}

Our research is based on data collected in the Sinto dairy farmer community through individual surveys (Aubron, 2006). First, 50 surveys were conducted over an eight-month period. The results allowed us to formulate an initial assessment of Sinto's agrarian situation. For an in-depth study of dairy farming practices over the long term, we followed the activities of eight families in detail on a monthly basis between October 2003 and September 2004. This also provided an opportunity to refine our quantitative estimates, particularly on time allocated to each activity over the course of an entire agricultural year in a highly variable environment. The eight families were selected according to the diversity of their means of production. The monitoring consisted of accompanying each family one day a month to observe all of their livestock production activities and interviewing the entire household to record the history of relevant events since the monitoring team's previous visit: cattle transfers between different areas, changes in the number of head and production levels, labor planning, dairy product sales, etc.

The amount of time allocated to cultivation, with the exception of irrigation, was counted in working days (man-day), differentiating among family labor (most often members of the nuclear family), the use (fairly rare) of agricultural day laborers, and mutual exchange of labor between community members. For irrigation, water shifts are organized by the group in charge of allocating water along the canal. As the shifts are usually organized on an hourly basis, we chose an hourly measure. We also evaluated husbandry activities by the hour. These were split into two categories - daily chores and seasonal work - using the terminology defined by the "bilan travail" ("labor balance") method (Dedieu et al., 2000). Working hours later were converted to working days on the basis of eight hours per day. Given that a working day can vary from five to twelve hours, this ratio is debatable. However, the conversion was necessary to aggregate data on cropping and livestock farming tasks, build readable, year-long labor schedules, and calculate the gross daily productivity of labor. Monitoring also produced data required for the calculation of two economic indicators that allow the measurement of gross productivity (daily and overall) of labor in Sinto - gross product $^{4}$ and intermediary consumption ${ }^{5}$.

In addition to the Sinto case study, we carried out bibliographical research on eight regions of Ecuador, Peru, and Bolivia (see Fig. 1). To complement this bibliographical work, we also surveyed dairy farmers during short stays in four dairy production areas. We formalized this analysis by constructing a typology of Andean dairy production systems and by comparing each system's gross productivity. Due to the absence of detailed data relative to the daily work routines in each production system, the daily productivity of labor could not be calculated. Although less precise, the global productivity of labor nevertheless provides a wealth of information that may be used to compare production systems competing in the same market. The information also may contribute to a discussion regarding how these systems may evolve in the future.

\footnotetext{
${ }^{4}$ Aggregate of the values of the products generated over the year estimated at their opportunity cost, be they sold or consumed by the household.

${ }^{5}$ Intermediate consumption consists of all the goods and services completely consumed as inputs in the year's production.
} 


\section{RESULTS: DAIRY FARMING IN THE ANDES: LABOR-INTENSIVE PRODUCTION}

\section{Labor investment in irrigated fodder production}

In Sinto, a household's dairy production is closely related to access to irrigated land required to cultivate alfalfa. The vital need for alfalfa explains why so much labor is invested in the crop. The potato crop, planted during the dry season, cannot be considered separately from alfalfa because Sinto farmers use a cropping system that rotates alfalfa and potatoes on their plots (see Fig. 2) so that the labor invested in potatoes must also be understood as labor invested in alfalfa. According to our calculations, the monitored households' alfalfa plots (97 plots) are plowed and newly planted every 13 years on average. Cultivation is entirely manual except for the transportation of harvested crops, which often are carried by donkeys or llamas. Shovels are used for irrigation; the soil is plowed with picks and heel bars; potatoes are harvested with hoes, and barley with sickles ${ }^{6}$.

Figure 2. Schedule of alfalfa cropping system

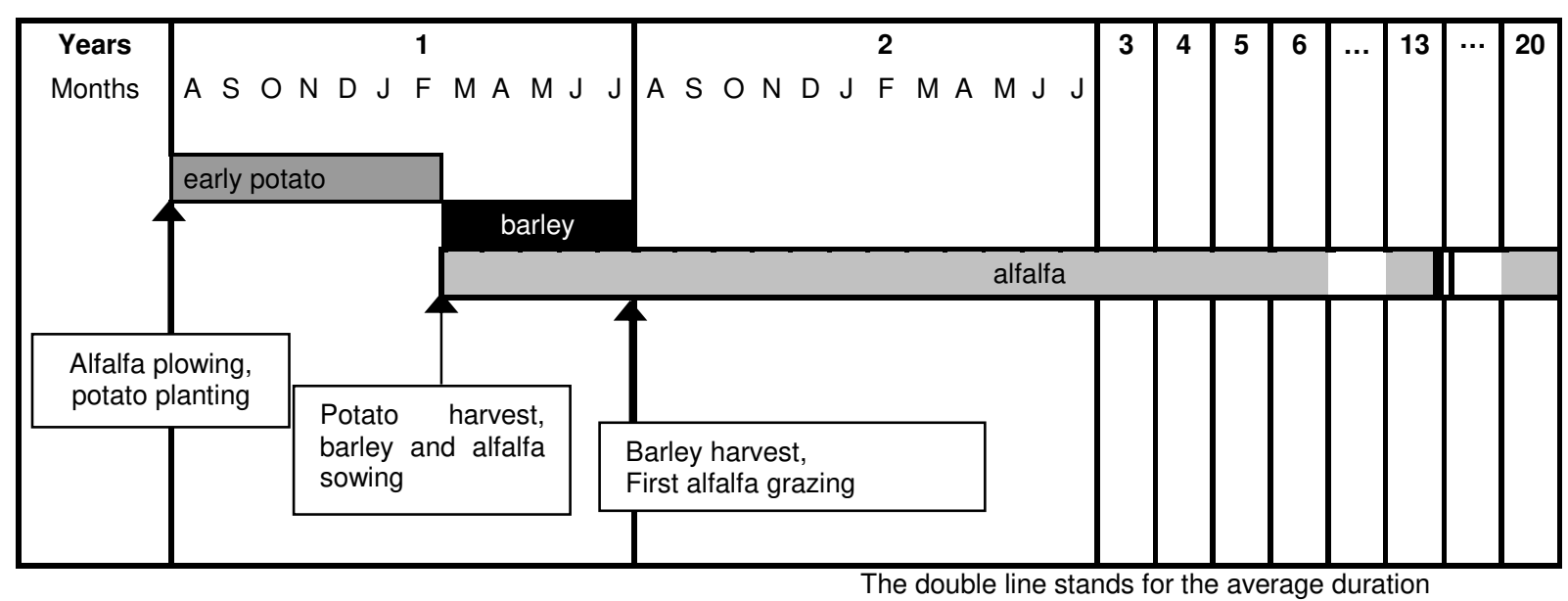

Most of the variations in labor time requirements on seven plots noted during monitoring related to the preliminary preparation of the land prior to potato planting, notably the condition of the plot (Fig. 3). First, the alfalfa plots are frequently overgrown by herbaceous plants such as kikuyo (Pennisetum clandestinum), forming a vegetal cover that is particularly thick and difficult to plow up. Secondly, if a new plot is to be established on previously nonirrigated areas, the canal must be extended to the plot, which must be cleared, stones removed, and sometimes terraced to limit the slope. All of these tasks are difficult and time-consuming. The preparation, plowing, and harvesting of potato plots are the most labor-intensive phases of the cropping system. The irrigation of newly-sown alfalfa plots also is delicate task due to the risk of seedlings being washed away. In addition to high water input requirements, our data show that preparing and planting alfalfa plots also requires considerable work, with an average of 660 person days per hectare. Consequently, the surface area of alfalfa plots that are recycled or newly planted every year is closely related to the labor force available within the household or that the household can afford to hire. The year we carried out our observations,

\footnotetext{
${ }^{6}$ In Sinto, farmers do not use the chaquitaclla (a manual plow typical of cropping systems involving collective rotations; Morlon et al., 1996) or the ox-hauled swing plows used in other Andean regions. They are not considered effective in Sinto because of the very small size of the plots, the lack of humidity, and the very stony soil.
} 
the surface area of alfalfa plots varied from 0 to 0.2 ha per family. The only task performed on a planted alfalfa plot is irrigation during the dry season. The time needed varies greatly depending on i) the volume of water available (extremely variable depending on the accessible canals); and ii) the plot size (a large plot allows considerable economies of scale).

Figure 3. Working times in the alfalfa cropping system, excluding alfalfa plots irrigation, for seven monitored parcels of different families (Sinto, 2003-2004)

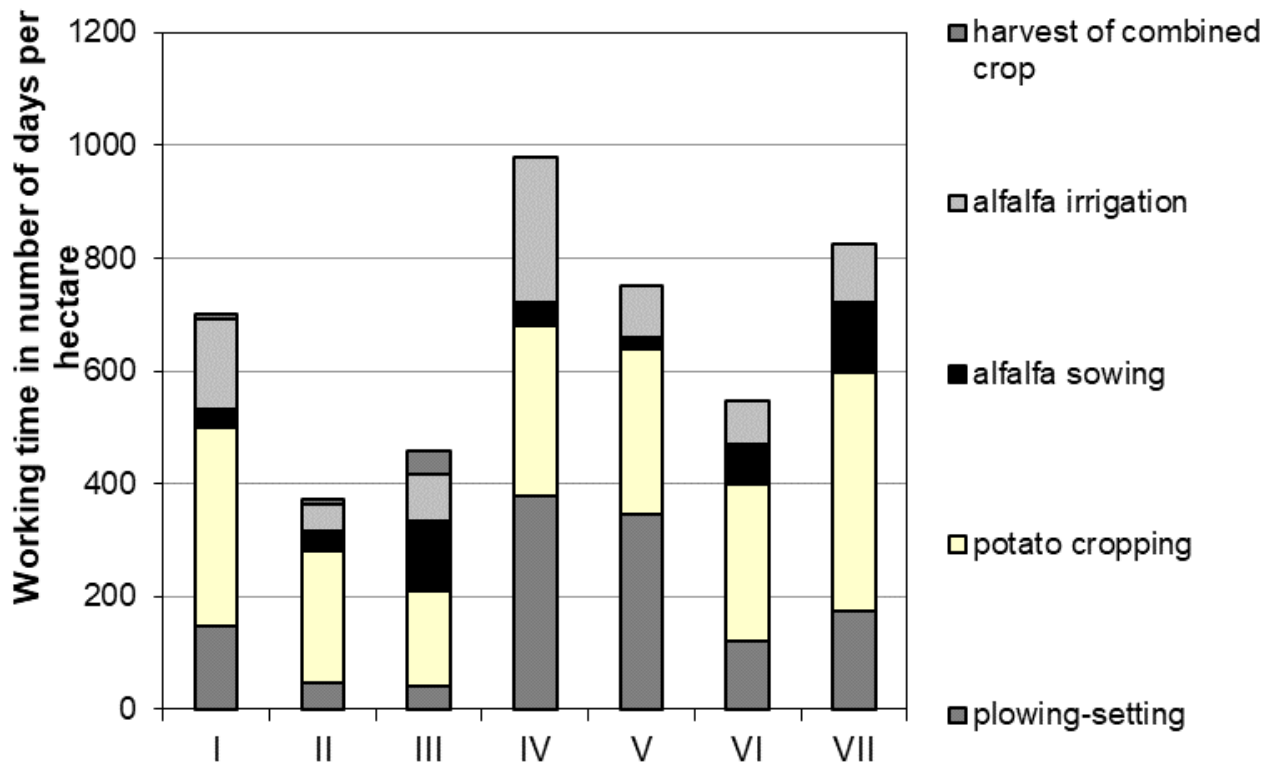

\section{Labor intensive mountain dairy farming}

For fodder management in Sinto cattle are split into two groups: milk-producing cows and their calves, used as triggers during milking; and all non-dairy cattle - dry cows, heifers, and bulls. The dairy group grazes every day on irrigated alfalfa plots under close supervision of their owners, while the non-dairy cattle graze freely on hundreds of hectares of rangelands (Aubron \& Brunschwig, 2008) which the farmers only visit once every two to four weeks to check the animals' health and move cattle if necessary (for example, cows ready to calve are taken down to the alfalfa plots).

Alfalfa plots are grazed in rotation for three to fifteen days and then are left for an average of 75 days. Supervising grazing is time-consuming: farmers spend four to six hours a day with the dairy cattle grazing alfalfa to ensure that they eat "something old, something new," as in strip grazing. They must also keep the older calves away from their mothers in order to limit loss of milk and prevent animals from wandering off the plot and possibly falling to their deaths. Dairy cows are milked once a day in the morning before grazing. It is the only task that is proportional to the number of animals: around ten minutes per cow.

Daily chores on Sinto farms consist of milking, cheese-making if applicable, grazing supervision, possibly cutting Stipa ichu, an Andean siliceous grass used to feed cattle in addition to alfalfa, and travel, with or without cattle. Seasonal work consists of moving cattle 
from one area to another (transferring a cow from one group to another or herding dairy cattle to a remote plot), visits to non-dairy cattle on rangelands, and cropping tasks. Excluding work related to fodder crops, farmers prioritize dairy production so that daily chores take precedence over seasonal work (see Fig. 4): dairy cattle are allocated not only the bulk of household labor but also the best fodder, which is limited. Farmers thereby ensure regular dairy production and hence stable income.

Figure 4. Livestock farming working times for each monitored household (Sinto, 2003-2004). The figures indicated for each household correspond to the average number of cows (co) and alfalfa hectares (ha) they own.

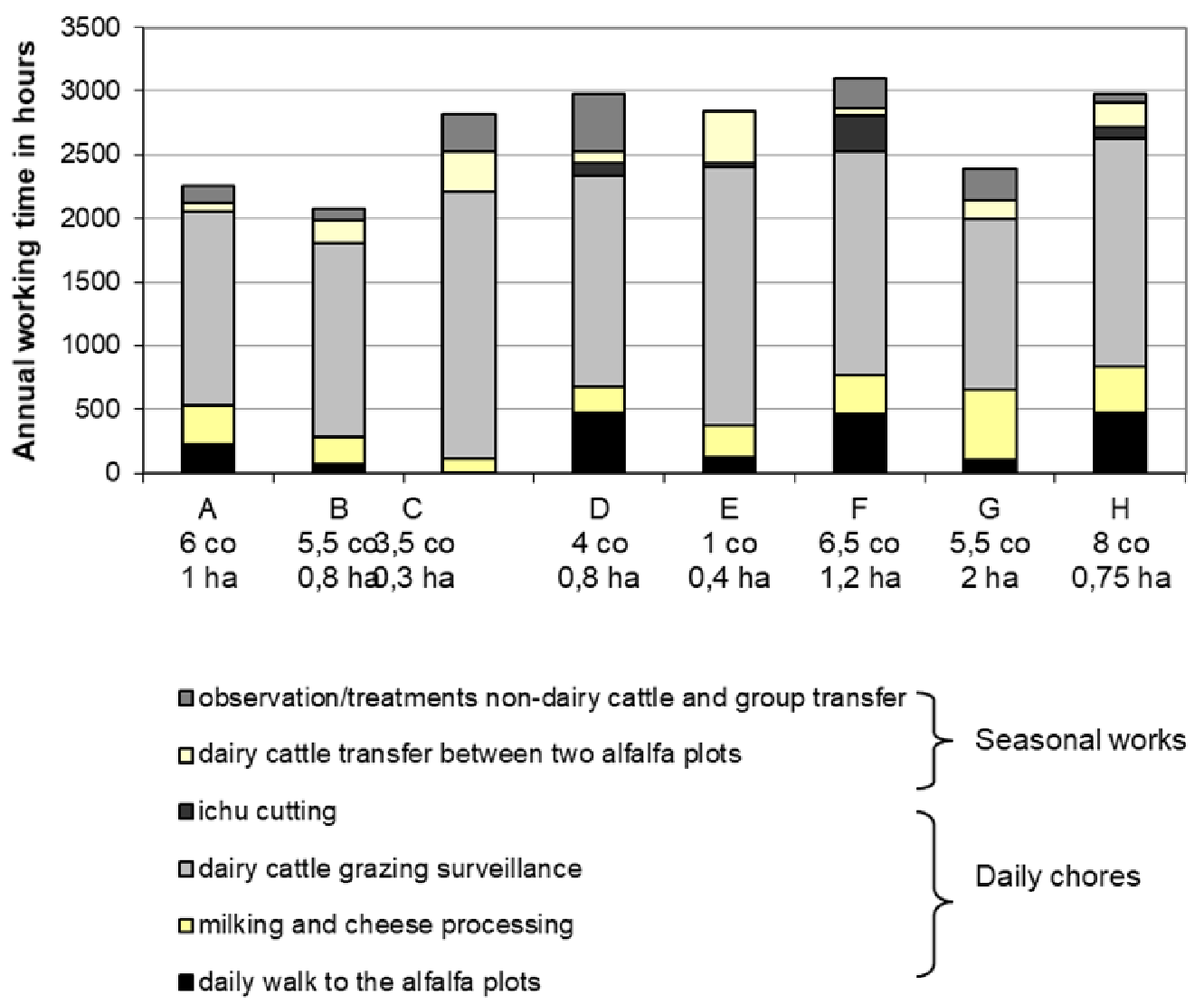

Dairy farming in the rugged terrain and dry climate of the Andean mountains is very laborintensive. Tilling prior to fodder cropping is done with manually requiring considerable manpower and results in an uneven plot pattern as alfalfa plots need to be established where steep slopes and rocky outcrops do not prevent access and movement. They also need to be located downstream of an existing canal (or in a place that can be irrigated by building a new one). As the plots are very small and scattered, alfalfa irrigation, cattle transfers, and daily grazing supervision take up a considerable amount of time. Collecting milk and maintaining its purity are also highly problematic issues for newly established small-scale milk processing units. Considering the very small size of the herds and their production levels, the considerable amount of labor required raises obvious questions concerning labor productivity. 


\section{Livestock farming: labor intensification and economic security}

Two very basic models were designed to study the productivity of labor in Sinto. Both are based on a household with one adult worker and one irrigated hectare of land dedicated to alfalfa. ${ }^{7}$ Under these conditions, a household has two options: either to sell standing alfalfa to an outsider every growth cycle (Model 1), or to graze their own cows on the plot to produce milk (Model 2). By selecting the first option, the only work is cropping; the second option entails all the daily and seasonal tasks related to husbandry. The household then may face labor shortages and be obliged to hire day laborers if their budget so permits. The comparison of the two models illustrates the logic of labor management in the production systems studied (Table I).

Table 1. Productivity of labor in Sinto production systems (Aubron, 2006)

\begin{tabular}{lccc}
\hline & $\begin{array}{c}\text { Number } \\
\text { of } \\
\text { necessary } \\
\text { labored } \\
\text { days }\end{array}$ & $\begin{array}{c}\text { Global productivity } \\
\text { of labor } \\
\text { (soles/worker/year) }\end{array}$ & $\begin{array}{c}\text { Daily } \\
\text { productivity } \\
\text { of labor } \\
\text { (soles/day) }\end{array}$ \\
\hline Model 1 : 1 worker, 1 irrigated hectare, alfalfa sale & 92 & 2155 & 23 \\
Model 2 : 1 worker, 1 irrigated hectare, dairy farming & 410 & 3275 & 8 \\
Dairy farming only & 318 & 1120 & 3 \\
\hline
\end{tabular}

There is a considerable difference in productivity between cropping and livestock farming activities. While the value added per worker per year is higher in the milking production system, the daily productivity of labor is much higher in the non-dairy production system (Model 1), because less labor is required: 23 soles (5.4 euros) per day compared to 8 . The daily productivity of labor devoted to husbandry (Model 2), measured by the ratio of the surplus value added derived from husbandry (1120 soles) and the quantity of labor dedicated to it (365 days), is only 3 soles per day (0.7 euros).

Despite such low productivity in terms of working days, Model 2 remains attractive to Sinto farmers: it provides a full-time job and increases the global productivity of labor by over $50 \%$, and hence the annual income per worker. It is a clear illustration of the phenomenon observed by Chayanov (1926) of the over-intensification of labor when farmers have little access to other means of production. Moreover, milk sales provide a fairy stable cash income and cattle are a form of capital that can be converted into cash when necessary (Siegmund-Schultze et al., 2007). Andean dairy farming systems therefore reflect the need of the household to both intensify labor and obtain economic security ${ }^{8}$.

\footnotetext{
${ }^{7}$ These characteristics are representative of an average Sinto household despite the variations that exist between households in terms of access to means of production. ${ }^{7}$

${ }^{8}$ Small ruminant (sheep and goats) husbandry often is combined with cattle farming in Sinto production systems for the same reasons. When they are bred in small numbers - five females at the most - they are incorporated into the dairy cattle herd. They provide supplementary income and improve the quality of the household diet (providing meat and milk) without requiring any extra labor. With more than five females, small ruminants are taken to the rangelands and an extra worker is required to watch over them.
} 


\section{The opportunity cost of dairy production labor}

The intensification of labor observed in Sinto generally relates to women. The daily chores that require at least one person are almost always performed by mothers, often assisted by children older than eight after they return from school. As in many other parts of the world, daily husbandry chores are considered women's work (Deere, 1982; Valdivia, 2001). Men's participation in these chores is minimal; they perform seasonal work: watching over non-dairy cattle on remote rangelands, irrigating alfalfa plots and, more generally, performing or supervising all cropping activity. However, with the exception of plowing, most of these tasks can be performed by women if their husbands are unavailable, which explains why some production units have only one worker.

Consequently, in the families monitored the adult males work on the farm for only half of the year. The production systems of Sinto thus allow for men to engage in economic activities away from the community. In the families monitored, husbandry activities, with the exception of fodder cropping, required an equivalent of 260 to 390 working days, almost all performed by women (Fig. 5). Cropping and irrigating accounted for 70 to 290 working days. The highest value was observed in an unusual case where the household had three adult workers. The second highest value was 180 days.

Figure 5. Cropping and livestock farming working times for each monitored household (Sinto, 2003-2004)

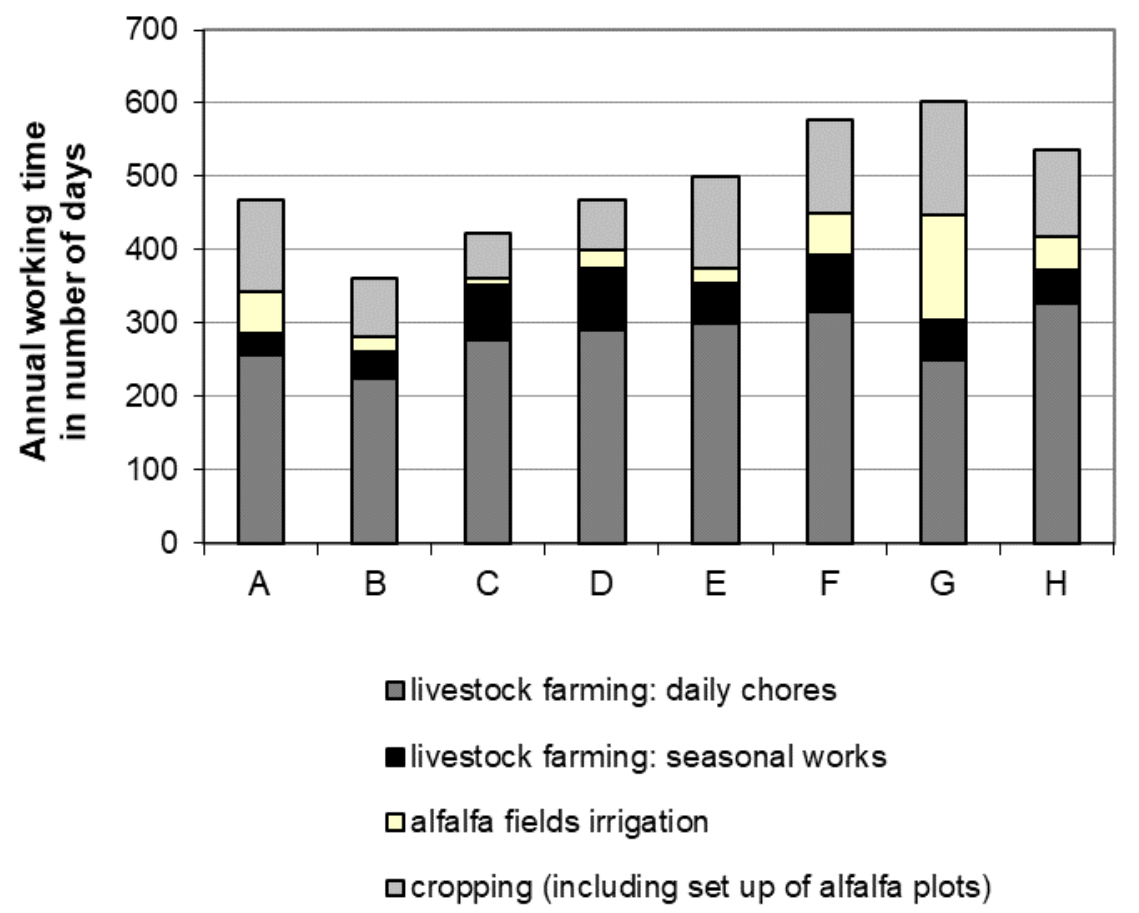

Some men have permanent jobs in government departments, mines, or schools in the region and thus may return home every weekend to take part in farming activities. However, most of the jobs are short-term contracts (from two weeks to three months) on construction sites and pay the Peruvian minimum daily wage of 20 soles. Some farmers also run small businesses with highly variable results depending on the time and money invested. The income from such activities and from the sale of cattle is used to cover important expenses (such as medical requirements, roof repairs, etc.). More regular income is usually spent on children's education in town. 
The comparison between the wages paid outside the production unit and the daily remuneration of agricultural labor is a means of evaluating the opportunity cost of labor. For a woman with a family in Sinto, it is nearly impossible to find a stable job that pays more than three soles a day. Hence the opportunity cost of female labor is close to zero. Although the remuneration of female labor on the farm is very low (three soles a day), it is still higher than its opportunity cost. Performing daily chores is not compatible with finding and working on off-farm jobs. In contrast, for men short-term contracts can be combined with farm cropping jobs, which are of relatively short duration and are spread out over the year. A man earns nearly twenty soles for every day he works, whether on or off the farm. Thus the opportunity cost of male labor is relatively high. However, this also means that men are underemployed during various periods of the year, unlike women.

To summarize: Sinto production systems require intensive female labor that generates income which, while low, is nevertheless stable and guaranteed. Since livestock farming can be undertaken by a single person, on the condition that she is present year round, the male work force is partially "liberated." Although planting alfalfa is very labor intensive, the crop can complete numerous growth cycles before the plot has to be plowed and replanted. Alfalfa cropping therefore also takes part in the "feminization of labor" that characterizes these dairy production systems. When men's labor is not required on the farm, the men are free to find non-farming activities, whether locally or outside the region. However, this balance between agricultural and non-agricultural activities is very fragile due to the highly unstable economic and geographic nature of non-farming activities (Phelinas, 2004). Furthermore, not all farmers have access to such activities, leading to differentiation among production units.

\section{Comparative productivity of dairy production systems in the Andes}

In Andean countries, dairy production systems differ according to variations in access to land and water for irrigation, two determining factors in cattle feeding patterns, as well as available labor. The availability of capital also affects the size and the breed of the dairy herd.

Most dairy farmers in the Andes feed cattle solely on rangelands and post-harvest crop residues (see Table 2). They typically own two to thirty cattle of the local criollo breed and milk production is concentrated during the rainy season. Year-round milk production requires farmers to plant fodder crops which must be irrigated or stored for the dry season. With most of the fodder produced manually using household labor, the number of dairy cows seldom exceeds ten head. Alfalfa cropping is very common in dry, inter-Andean valleys and on the western side of the Andes (Roman, 1988). In the northern, more humid areas (Cajamarca), the clover - ray grass combination is preferred (Malpartida et al., 1994; Bernet \& Tapia, 1999). On the altiplano and around the city of Huancavelica, where there is little irrigation, dairy production is intensified by planting oats which are stored as hay or silage and used to feed cattle during the dry season (Hervé \& Rojas, 1994). However, a distinction should be made between farms where cattle graze rangelands in addition to being fed fodder crops (whether at certain times of the year or only for part of the herd) and farms where cattle are exclusively, or almost exclusively, fed fodder crops. The latter usually enjoy a more favorable location and better land access. On such sites, Holstein and Brown Swiss cows are preferred to criollos, which are less productive and of littel interest outside the rangeland grazing environment (Hervé, 1992). 
Table 2. Typology of Andean dairy production systems (Aubron, 2006)

\begin{tabular}{|c|c|c|c|c|c|c|c|}
\hline Type & Feeding pattern & Breed or type & Size of herd & $\begin{array}{l}\text { Labor } \\
\text { force }\end{array}$ & $\begin{array}{c}\text { Dairy } \\
\text { production } \\
\text { (liters/cow } \\
\text { /day) }\end{array}$ & $\begin{array}{c}\text { Dairy } \\
\text { production } \\
\text { (liters/ } \\
\text { household/ } \\
\text { day) }\end{array}$ & $\begin{array}{l}\text { Region } \\
\text { example }\end{array}$ \\
\hline 1 & $\begin{array}{l}\text { Crop residue and } \\
\text { rangelands }\end{array}$ & & $2-8$ cows & Family & $1-2$ & $2-15$ & Huancavelica \\
\hline 2 & $\begin{array}{l}\text { Rangelands and } \\
\text { crop residue }\end{array}$ & Criollo & 9-30 cows & Family & $1-2$ & $9-60$ & High-Cañete \\
\hline 3 & $\begin{array}{c}\text { Irrigated fodder } \\
\text { crop and rangelands }\end{array}$ & $\begin{array}{l}\text { Criollo } \\
\text { Criollo }\end{array}$ & $2-8$ cows & Family & $3-6$ & $6-50$ & $\begin{array}{l}\text { Western } \\
\text { slope, } \\
\text { Cajamarca } \\
\text { (Jalca) }\end{array}$ \\
\hline 4 & $\begin{array}{l}\text { Dry or irrigated } \\
\text { fodder crop and } \\
\text { rangelands }\end{array}$ & $\begin{array}{c}\text { Crossed } \\
\text { criollo - } \\
\text { brown swiss } \\
\text { or holstein }\end{array}$ & $2-8$ cows & Family & $5-10$ & $10-80$ & $\begin{array}{l}\text { Altiplano, } \\
\text { Cajamarca } \\
\text { (slope), } \\
\text { Ecuador }\end{array}$ \\
\hline 5 & $\begin{array}{l}\text { Irrigated fodder } \\
\text { crop and } \\
\text { concentrates }\end{array}$ & $\begin{array}{l}\text { Brown swiss } \\
\text { or holstein }\end{array}$ & $2-8$ cows & Family & $8-25$ & $15-200$ & $\begin{array}{c}\text { Arequipa, } \\
\text { Cajamarca } \\
\text { (valley) }\end{array}$ \\
\hline 6 & $\begin{array}{l}\text { Irrigated fodder } \\
\text { crop and } \\
\text { concentrates }\end{array}$ & $\begin{array}{l}\text { Brown swiss } \\
\text { or holstein }\end{array}$ & $9-100$ cows & Hired & $8-25$ & $70-2500$ & $\begin{array}{c}\text { Arequipa, } \\
\text { Cajamarca } \\
\text { (valley) }\end{array}$ \\
\hline
\end{tabular}

In the Andean region, the only dairy production systems that do not require seasonal cropping work are entirely off-soil production systems (which are very rare) and those based exclusively on rangelands. The chores related to cattle feeding usually are the most demanding, whether for supervised grazing, tethered grazing, or fodder distribution. Fodder distribution (two to four hours daily) is less time-consuming than supervision of grazing, but cutting and carrying fodder is a tougher job. In all three cases, the amount of time required to transfer cattle and carry fodder depends greatly on the landholding of the farm. Geographical constraints also crucially determine the time necessary to transport dairy products from the farm to points of sale - daily if the milk is sold to an industrial plant or cheese factory, and weekly if farmers make their own cheese. Milking usually is done manually, usually once a day, and takes between 30 minutes to one hour depending on the number of cows.

Overall, all Andean dairy production systems require the presence of one worker every day to carry out the necessary tasks; however, the working hours involved vary. Comparing two systems in which only the work load differs - for example, tethered grazing around the house and the Sinto system - the hourly productivity of labor may vary but the daily productivity will be equal. In Sinto, labor intensification allows the maintenance of dairy production, but it has lower hourly productivity than tethered grazing systems. Seasonal work may be performed by the same worker if not much labor is required and if it can be fitted into the timetable of daily chores. If not, an extra, part-time worker is needed for seasonal work.

The volume of milk produced by these different systems obviously varies (Table 3): small herds on rangelands produce less than ten liters a day and only during the rainy season, while systems that combine rangeland with fodder crop feeding may produce several hundreds of liters per day. This figure may even reach several thousand when access to resources and the hiring of wage laborers makes it possible to raise ten or more head of a productive breed fed 
exclusively with fodder crop and concentrates. The price of milk paid to farmers - or its equivalent in the case of cheese processing - can vary slightly from one region to another within Peru due to both transportation costs and social relationships within production chains.

Table 3. Productivity of labor in Andean dairy production systems

\begin{tabular}{|c|c|c|c|c|c|c|}
\hline Type & $\begin{array}{l}1 \\
\text { Small criollo- } \\
\text { type herd on } \\
\text { rangelands } \\
\text { and crop } \\
\text { residue }\end{array}$ & $\begin{array}{c}2 \\
\text { Large criollo- } \\
\text { type herd on } \\
\text { rangelands } \\
\text { and crop } \\
\text { residue }\end{array}$ & $\begin{array}{c}3 \\
\text { Small criollo- } \\
\text { type herd on } \\
\text { rangelands } \\
\text { and fodder } \\
\quad \text { crop }\end{array}$ & $\begin{array}{c}4 \\
\text { Small } \\
\text { improved- } \\
\text { breed herd on } \\
\text { rangelands } \\
\text { and fodder } \\
\text { crop } \\
\end{array}$ & $\begin{array}{c}5 \\
\text { Small } \\
\text { improved- } \\
\text { breed herd on } \\
\text { fodder crop } \\
\text { and } \\
\text { concentrates }\end{array}$ & $\begin{array}{c}6 \\
\text { Large } \\
\text { improved- } \\
\text { breed herd on } \\
\text { fodder crop } \\
\text { and } \\
\text { concentrates }\end{array}$ \\
\hline Number of cows & 3 & 10 & 5 & 5 & 6 & 20 \\
\hline Number of workers & 1 & 1 & 1.2 & 1.2 & 1.2 & 2.2 \\
\hline $\begin{array}{l}\text { Annual dairy } \\
\text { production volume } \\
\text { (L/household/yr) }\end{array}$ & 240 & 2750 & 3200 & 7300 & 16425 & 135050 \\
\hline $\begin{array}{l}\text { Milk price paid to } \\
\text { the farmer } \\
\text { (soles/L) }\end{array}$ & 0.85 & 0.9 & 0.75 & 0.7 & 0.72 & 0.75 \\
\hline $\begin{array}{c}\text { Dairy annual Gross } \\
\text { Product } \\
\text { (soles/year) }\end{array}$ & 204 & 2475 & 2400 & 5110 & 11826 & 101288 \\
\hline $\begin{array}{c}\text { Meat annual Gross } \\
\text { Product } \\
\text { (soles/year) }\end{array}$ & 278 & 1300 & 850 & 1000 & 1600 & 6200 \\
\hline $\begin{array}{l}\text { meat GP / } \\
\text { total GP }\end{array}$ & $58 \%$ & $34 \%$ & $26 \%$ & $16 \%$ & $12 \%$ & $6 \%$ \\
\hline $\begin{array}{l}\text { Added value of } \\
\text { other productions } \\
\text { (soles/year) }\end{array}$ & 1500 & 500 & 1500 & 700 & 200 & 0 \\
\hline $\begin{array}{l}\text { Intermediate } \\
\text { consumptions } \\
\text { (soles/year) }\end{array}$ & 60 & 250 & 350 & 600 & 4200 & 20530 \\
\hline $\begin{array}{c}\text { Total added value } \\
\text { (soles/year) } \\
\text { Global gross } \\
\text { productivity of } \\
\text { labor } \\
\text { (soles/worker/year) }\end{array}$ & 1922 & 4025 & 4400 & 6210 & 9426 & 86958 \\
\hline
\end{tabular}

Production systems can be further differentiated according to the importance of meat production. Fodder crop and concentrate feeding patterns often entail the early sale of males for meat at one to nine months, whereas cattle bred in rangeland systems are sold at two to five years. Fattening cattle has both a monetary cost (purchasing fodder and concentrate) and an opportunity cost, as the fodder allocated to the males could be sold or used to produce milk. However, the absolute value of meat products in fodder and concentrate production systems is not necessarily lower given that the males are bigger even if sold at an earlier age. 
In order to evaluate the productivity of labor, we also have to take into account other production incorporated into dairy production that is generated without any extra work. This is the case of subsistence crops produced through fodder cropping systems and of small ruminants incorporated into the dairy herd. These estimates were based on the observations made in Sinto.

Intermediate consumption is extremely variable among production systems. It is very low in systems based on rangelands where it consists of the occasional purchase of veterinary care and standing fodder. It is high in production systems based on fodder and concentrates because these two inputs alone cost on average two soles a day per cow (0.46 euros), and there are also additional expenditures on veterinary care and artificial insemination.

There are significant differences among the six production systems presented here, although they are less than the differences among household dairy production units: the overall gross productivity of labor in rangeland dairy systems is approximately 2,000 soles per worker per year (500 euros), twenty times lower than production systems based on large herds of improved breeds (around 40,000 soles or 10,000 euros). As competition among different production systems causes prices to align with those sustained by the most competitive systems, a very important gap appears in terms of the remuneration of labor. As previously shown, Andean dairy farmers produce milk despite low labor productivity in part because the labor force, particularly females, has a very low opportunity cost. Yet the cost of maintaining this production has been sharp inequalities in incomes and development. This is unlikely to change in coming years as the recent free trade agreements signed by Peru will allow very competitive dairy producers from countries such as Argentina to enter the Peruvian market.

\section{DISCUSSION: LABOR PRODUCTIVITY AS A KEY FOR UNDERSTANDING FARMING SYSTEMS}

\section{Revealing the technical coherence of cropping and livestock farming systems}

The precise description of the daily chores and seasonal tasks performed and their agronomic and zootechnical consequences reveals the technical coherence of cropping and livestock farming systems. In Sinto the study of labor at the level of alfalfa plot cropping and livestock farming systems highlights the problems faced by farmers and the practical ways they respond to them. From an operational perspective, the information can be used to evaluate solutions available to increase labor efficiency and the advantages or disadvantages of proposed technical changes.

The supervision of dairy cattle during alfalfa grazing allows farmers to verify that the animals eat properly, to limit the quantity of milk loss and to prevent accidents. However, tether grazing would allow the same functions to be fulfilled if the pole and tether were moved several times a day while the watching time would be reduced. The reason for not adopting tether grazing is probably that the additional walking time needed would offset the gains in watching time. The round-trip journey to the alfalfa plots takes up to three hours per day. The dispersion of plots offers the advantage of reducing risks. Travel time between irrigated plots could be reduced by swapping plots between families, as is done in other Andean regions (Mayer \& Fonseca, 1988). But as long as such regrouping of plots is not undertaken, tether grazing is not a realistic solution for Sinto farmers. 
Our study also highlights the relevance of the concepts of cropping and livestock farming systems. The unity of a cropping system derives from the whole sequence of cultivation operations performed on that area for a succession of crops (Sébillote, 1978). The example of alfalfa cropping proves the advantage of reasoning at this level: the significant amount of labor required to set up an irrigated plot in Sinto, and perhaps even to harvest potatoes, can only be understood in terms of the fodder crop production it will provide over the years. When this perspective is applied to livestock farming systems in Sinto, it is necessary to reevaluate the distinction between cattle farming systems and small ruminant farming systems with less than five females. As the goats or sheep are totally incorporated into the dairy herd and do not generate any extra work or costs, it may be more appropriate to consider the whole as a pluri-specific livestock farming system, endowed with a proper technical coherency.

\section{Understanding labor force allocation between different activities over the year}

The calculation of hourly or daily productivity of labor at the level of a cropping or livestock farming system allows comparison of the economic efficiency of labor and its remuneration, and thereby measurement of the opportunity costs of the labor force for different activities to understand farmers' decision making. In Sinto, for instance, the lower productivity of labor in raising small ruminants explains why farmers dedicate themselves to dairy farming. For this reason, only households that have an extra available worker (an elderly person or a young girl that does not attend school) or that do not have access to irrigated land raise large numbers of sheep and goats in addition to cattle.

The calculation of the global and daily productivity of labor also helps to illuminate the combination of activities within a production (or activity) system during the year, as well as how labor is allocated. Undertaking activities that do not compete in terms of labor can increase global productivity although it may reduce daily productivity. In Sinto, combining the alfalfa cropping system with a dairy farming system is an example of this logic: when somebody works on the farm full-time, the daily productivity of labor diminishes but the work schedule is fuller which allows the global productivity of labor to increase. Similarly, men sometimes take on non-farming activities during periods when no cropping work needs to be done thereby increasing the global productivity of their labor. Labor allocation adjustments can sometimes be made to better combine different activities (deep plowing and ridge plowing before or after potato planting in Central Andes, Morlon et al., 1996; use of precocious varieties of rice to spread work peaks over a larger period of time in Amazonia, White et al., 2005). Nevertheless, such adjustments are less likely in livestock farming systems due to the importance of daily chores (Dedieu et al., 1999). Furthermore, the different workers within a production unit are not always interchangeable. Labor allocation has to take into account that certain tasks can only be performed by men, women, or children (Stieff, 1997; Valdivia, 2001).

\section{Comparing production systems and their future prospects}

Lastly, considering labor and measuring its productivity within the framework of a production system provides important insights into the dynamics of agrarian systems. It allows one to acknowledge the diversity of existing production systems, to compare their outputs, to estimate their capacity to face competition, and to measure inequalities in development generated. It also provides data that can be used to estimate the consequences of price changes on the household economies of different categories of farmers. Applied to Peruvian dairy production, this approach highlights very important productivity gaps (twenty-fold) that 
derive from differentiated access to resources. It also emphasizes the low remuneration of labor in marginal dairy areas where cattle are fed almost exclusively on rangelands and measures the risk of a decline in living standards resulting from the opening of the Peruvian market to more competitive countries.

By considering the question from the angle of a comparative study of the productivity of labor and income, the approach we developed around dairy systems in the Andes has helped to identify indicators that may better reflect the diversity of production systems competing with each other in a given market. These indicators also help to evaluate the incomes, employment, and inequalities generated by different forms of production and their prospects for the future. The notion, "production system competitiveness", therefore is understood as having a meaning broader than "cost-competitiveness" - the aim to maintain or strengthen market share - alone.

In this respect, it would be interesting to measure the productivity of labor in other dairy production systems in countries which produce and trade (or potentially may trade) dairy products with Andean countries, to estimate their competitiveness in the Peruvian market (after adding the costs of milk powder processing and transportation). This would allow for the calculation of measures needed to protect Peruvian producers. Finally, it would be interesting to combine this approach focused on the economic efficiency of labor with a comparison of different patterns of wealth distribution, namely to compare the income of each group of producers. For example, in regions where land rent is very high, the distribution of added value between farmer and owner may increase inequalities in development generated by gaps in labor productivity.

\section{CONCLUSION}

The technical and economic characterization of labor at different levels is thus a key for understanding agricultural systems, allowing the identification of both the problems faced by farmers and the cropping and livestock farming practices they implement to overcome these problems. It highlights the logic of labor force allocation in production and activity systems, facilitating understanding of how these systems function. Finally, at the regional level, it allows comparison of different production systems competing in the same market and to assess their future prospects.

Socioeconomic and anthropological approaches emphasize the role of labor in social interactions and in the definition of an individual's identity (Laurent, 2005). In agriculture, this human factor may be exchanged within "work groups" whose composition and size can vary greatly over time (Harff \& Lamarche, 1999), but also through the wage system, share cropping, and even servitude (Turner, 1999). The issue of identity, which surpasses the scope of this article, is nevertheless revealed in this Andean study, where livestock husbandry is identified as women's work. This being the case, the frequent travel of men to seek employment on off-farm work sites is accompanied by a profound redrawing of identities in the Andean region (Cortes, 2000).

\section{REFERENCES}

Attonaty, J.M., Laporte, C., Papa, F., and Soler, L.G., (1987). La simulation de l'organisation du travail comme outil de gestion de l'exploitation agricole. Application à la grande culture. Etudes et Recherches sur les Systèmes Agraires et le Développement 10: 1-48.

Aubron, C., (2005). Individus et collectifs dans l'appropriation des ressources : le cas d'une communauté andine péruvienne. Autrepart 34: 65-84. 
Aubron, C., (2006). Le lait des Andes vaut-il de l'or ? Logiques paysannes et insertion marchande de la production fromagère andine. $\mathrm{PhD}$ thesis, INA P-G.

Aubron, C., and Brunschwig, G., (2008). Practices consistency in dairy farms of the dry Andes: analysis in a Peruvian peasants community. Livestock Research for Rural Development 20(30).

Aubron, C., and Cochet, H., (In Press). Produccíon lechera en los Andes peruanos: ¿Integración al mercado interno o marginación económica? Anuario Americanista Europeo 4.

Ayantunde, A.A, Willimas, T.O., Udo, H.M.J., Fernández-Rivera S., Hiernaux P., and van Keulen, H., (2000). Herders' Perceptions, Pratice, and Problems of Night Grazing in the Sahel: Case Sutides form Niger. Human Ecology 28: 109-130.

Bernet, T., and Tapia, M., (1999). Análisis de los Sistemas de Producción en la Microcuenca de la Encañada Cajamarca. Documento Base para investigaciones Futuras en la Sierra Norte del Perú, Documento de trabajo CIP, Lima.

Bernet, T., Staal, S., and Walker, T.S., (2001). Changing milk production trends in Peru: Small-scale highland farming versus coastal agrobusiness. Moutain Research and Development 21: 268-275.

Chayanov, A.V., (1986). The Theory of Peasant Economy, University of Wisconsin Press, Madison (original edition 1926).

Cochet, H., (2001). Crises et révolutions agricoles au Burundi, Karthala, Paris.

Cochet, H., (2005). L'Agriculture Comparée. Genèse et formalisation d'une discipline scientifique, INA P-G, Paris.

Cochet, H., and Devienne, S., (2006). Comprendre l'agriculture d'une région agricole : question de méthode sur l'analyse en termes de systèmes de production. Cahiers Agricultures 15: 578-583.

Cortes, G. (2000). Partir pour rester. Survie et mutation de sociétés paysannes andines (Bolivie), IRD, Paris.

Dedieu, B., Laurent, C., and Mundler, P., (1999). Organisation du travail dans les systèmes d'activités complexes. Intérêt et limites de la méthode Bilan Travail. Economie Rurale 253: 28-35.

Dedieu, B., Chauvat, S., Servière, G., and Tchakérian, E., (2000). Bilan travail pour l'étude du fonctionnement des exploitations d'élevage, INRA - Institut de l'Elevage Technipel, Paris.

Deere, C.D., (1982). The division of labor by sex in agriculture: A Peruvian Case study. Economic Development and Cultural Change 30: 795-811.

Dollfus, O., (1982). Development of land-use patterns in the central Andes. Moutain Research and Development 2: $39-48$.

Gonzales de Olarte, E., (1984). Economía de la comunidad campesina, IEP, Lima.

Harff, Y., and Lamarche, H., (1998). Le travail en agriculture : nouvelles demandes, nouveaux enjeux. Economie Rurale 244: 3-11.

Hervé, D., (1992). Adaptación a los sistemas agrarios andinos de un modelo de intensificación lechera. SEPIA IV: $347-369$.

Hervé, D., and Rojas, A., (1994). Vías de la intensificación de la ganadería lechera en el altiplano boliviano, ORSTOM - DANCHURCHAID, La Paz.

Hervé, D., Genin, D., and Migueis, J., (2002). A modelling approach for analysis of agro pastoral activity at the one-farm level. Agricultural Systems 71: 187-206.

Hunt, R.C., (2000). Labor Productivity and Agricultural Development: Boserup Revisited. Human Ecology 28: 251-277.

Landais, E., (1987). Recherches sur les systèmes d'élevage. Questions et perspectives, INRA URSAD, Paris.

Laurent, C., (2005). Multifunctionality of activities, plurality of identities and new institutional arrangements. Capitalisation of research results on the multifunctionality of agriculture and rural areas. Sixth Framework Research Programe, Global Change and Ecosystems - Multiagri Project, Paris.

Le Gal, P.-Y., (1997). From decision-making process analysis to modelling and simulation of farm management: application to work organization in two rice-based farming systems. In Teng P.S. (ed.), Systems Approaches for Agricultural Development Applications of Systems Approaches at the Farm and Regional Levels Volume 1, Dordrechet, Kluwer Academic Publishers, Dordrecht, pp. 137-152.

Madelrieux, S., Dedieu, B., and Dobremez, L., (2006). ATELAGE : un modèle pour qualifier l'organisation du travail dans les exploitations d'élevage. INRA Productions Animales 19: 47-57.

Malpartida, E., Pinares, C., and Bello, J., (1994). Sistemas de producción de la cuenca lechera de Cajamarca. In Hervé, D., and Rojas, A. (eds.), Vías de intensificación de la ganadería lechera en el altiplano boliviano, ORSTOM - DANCHURCHAID, La Paz, pp. 83-92.

Mayer, E., (1985). Production Zones. In Mazuda, S., Shimada, I., and Morris, S., Andean Ecology and Civilization: an Interdisiciplinary Perspective on Andean Ecological Complementarity, Tokyo Press, Tokyo, pp. 45-84.

Mayer, E., (2002). The Articulated Peasant: Household Economies in the Andes, Westwiew Press, Boulder.

Mayer, E., and Fonseca, C., (1988). Comunidad y producción. In Fonseca, C., and Mayer, E. (eds.), Comunidad y producción en la agricultura andina, FOMCIENCIAS, Lima, pp. 97-106. 
Mazoyer, M., (1987). Dynamique des Systèmes Agraires, Rapport de synthèse présenté au Comité des systèmes agraires, Ministère de la Recherche et de la Technologie, Paris.

Nielsen, U., Mertz, P., and Tonga Noweg, G., (2006). The Rationality of Shifting Cultivation Systems: Labor Productivity Revisited. Human Ecology 34: 201-218.

Morlon, P., Bourliaud, J., Reau, R., and Hervé, D., (1996). Una herramienta, un simbolo, un debate : la agricultura andina. In Morlon, P.(ed.), Comprender la agricultura campesina en los andes centrales Perú - Bolivia, IFEA - CBC, Lima, pp. 38-83.

Orlove, B. S., and Godoy, R., (1986). Sectoral Fallowing Systems in the Central Andes. Journal of Ethnobiology 6: $169-204$

Phelinas, P., (2004). L'emploi complémentaire en milieu rural péruvien : la richesse des pauvres ? Economie Rurale 282: 40-58.

Roman, C., (1988). La ganadería lechera en la Cuenca alta del Cañete, su rol en el desarrollo de los sistemas agrarios y su articulación al mercado nacional. In Eresue, M., and Brougere, A.-M. (eds.), Políticas agrarias y estrategias campesinas en la cuenca del Cañete, UNALM - IFEA, Lima, pp. 85-97.

Ruben, R., Kruseman, G., and Kuyvenhoven, A., (2006). Strategies for sustainable intensification in East African highlands: labor use and input efficiency. Agricultural Economics 34: 167-181.

Sébillotte, M., (1978). Itinéraires techniques et évolution de la pensée agronomique. Compte Rendu Académie de l'Agriculture France 11: 906-913.

Siegmund-Schultze, M., Rischkowsky, B., de Veiga, J.B., and King, J.M., (2007). Cattle are cash generating assets for mixed smallholder farms in the Eastern Amazon. Agricultural Systems 94: 738-749.

Stieff, D.F., (1997). Herding Strategies of the Datoga Pastoralists of Tanzania: Is Household Labor a Limiting Factor. Human Ecology 25: 519-544.

Turner, M.D., (1999). Labor Process and the Environment: The Effects of Labor Availability and Compensation on the Quality of Herding in the Sahel. Human Ecology 27: 267-296.

Valdivia, C., (2001). Gender, Livestock assets, resource management, and food security: Lessons from the SRCRSP. Agriculture and Human Values 18: 27-39.

White, S.D., Labarta, R.A., and Leguía, E.J., (2005). Technology adoption by resource-poor farmers: considering the implications of peak-season labor costs. Agricultural Systems 85: 183-201. 